\title{
The Role of Pharmacists in Kırklareli (Turkey) as Primary Health Care Providers
}

\author{
M. Eşref Tatlıpınar', Yılmaz Göksu², Gülden Z. Omurtag ${ }^{1 *}$ \\ ${ }^{1}$ İstanbul Medipol University, School of Pharmacy, Department of Pharmaceutical Toxicology 34810, İstanbul, Turkey. \\ ${ }^{2}$ Kuleli St. No: 27/11 Gaziosmanpaşa, Çankaya, Ankara, Turkey.
}

\begin{abstract}
This study was carried out in Kurklareli in 2005. The aim was to investigate the role of pharmacists as primary health care providers. In $63.5 \%$ of the total number of 55 pharmacies taking part in the research, there was no health care service within a 150 meter range. The remaining pharmacies, constituting $36.4 \%$, did have health care services within a 150 meter range. These were in the proximity of either village clinics (55\%), state hospitals (35\%), or private hospitals (10\%). $51.9 \%$ of the pharmacists are female and $48.1 \%$ male, and usually, they employ 1 or 2 assistants; only $1.9 \%$ do not employ an assistant. The assistants are between the ages of 20-29, and most of them are high school graduates. $27.4 \%$ of them work 10 hours a day, and $43.5 \%$ of them work 11 hours a day. $23.3 \%$ of the medicine sold in pharmacies in the most recent week of the study was unprescribed. $84 \%$ of the pharmacists told the patient to inform them of any adverse reactions and/or side effects. In the case of adverse reactions and/or side effects, $57.7 \%$ of patients informed the pharmacist before consulting a doctor. $100 \%$ of the pharmacists guided the patient to TÜFAM (The National Pharmacovigilance Centre-in Turkey). Pharmacists encounter drug poisoning very infrequently (5.7\%) and respond to it $100 \%$ of the time. In the most recent week of the study, no one applied for an HIV test. $94.1 \%$ of the pharmacists do not approve of the selling of over-the-counter drugs. As a result of this study, we learned that provisions for the primary health care services given at pharmacies were not present in existing legislation, although there is a demand for them in the affected communities.
\end{abstract}

Key words: pharmacist, primary health care, prescribed medicines, non-prescribed medicines.

\section{INTRODUCTION}

The concept of Primary Health Care Service first came to light in 1978 at a conference organized by the World Health Organization (WHO) and the United Nations International Children's Emergency Fund (UNICEF) in Kazakhistan's capital city Alma Ata. ${ }^{1}$ According to the declaration made there, Primary Health

*Corresponding author: Gülden Z. Omurtag

E-mail address: gzomurtag@medipol.edu.tr 
Care Systems (PHCS) form the first link in a National Health Care System. The declaration stressed the importance of having access to a health care service chain as close as possible to people's homes and workplaces. ${ }^{1}$ Pharmacies are by their very nature the first links in the health care chain. Health care services are divided into three groups: preventive medicine services, therapeutic health care services, and rehabilitation services. Preventive medicine services are also divided into two groups: outreach services and personalized services. Personalized services are carried out by healthcare professionals such as doctors, nurses and obstetricians. ${ }^{2}$

Because pharmacy services are included in personalized health care services, pharmacists should guide patients to consult doctor, and instruct them on how to use their drugs properly. Three sectors need to be considered with regard to health care services:

Folk sector. This sector is rejected by scientific medicine and official health care services. It is made up of people who are not officially educated or trained about health, but are the nonetheless considered an expert by society. Examples of people in this group are those who treat fracture-dislocation conditions, and obstetricians without diplomas.

Popular sector. This sector is made up of people who are not educated about health but considered as knowledgeable by people that they know. This group includes people like mothers, fathers, friends and elders.

Professional sector. This sector is made up of people who are formally educated and considered to be professionals by the scientific community. This group includes doctors, dentists, pharmacists, veterinarians, and nurses. Only a fraction of the health care services produced and consumed in societies are served by this sector. ${ }^{3,4}$

People often buy medicine from pharmacies after telling their complaints to the pharmacist on duty. and the purchase of medicine without prescription is quite common. This condition shows that pharmacies also serve as a part of the 'popular sector'. In Turkey, pharmacies are the most common health care unit used by the public as a primary health care service provider. Therefore, pharmacies play a key role in the use of prescribed medicine and in increasing consciousness about the proper use of prescribed medicine. The role of pharmacists in Primary Health Care Services has become a common topic in recent years in discussions between the WHO and the International Pharmaceutical Federation (FIP). ${ }^{5}$ The role of pharmacies is better understood after a comparative analysis of health institutions, the number of pharmacies and applications to these places in both developed or developing countries; when evaluating data related to purchasing 
unprescribed medicine, the role of pharmacies in these services is also better understood. ${ }^{6,7}$ In 1980 , the total number of pharmacies was 6.488 , but by 1990 , this number had reached 12.397 , a $99 \%$ increase. ${ }^{8}$ Today (2017) the number is 24.935 according to the provincial health directorate pharmacy license module. At the same time, the population per health clinic exceeded the population per pharmacy. Local research suggests that our people are prone to use medication without prescription, and, upon getting sick as a result, consult their doctor on their own initiative, or at a pharmacist's recommendation. ${ }^{9,10}$ Patients either have these medications in their home already, or they purchase them from pharmacies. ${ }^{11}$ Sometimes it is observed that expired prescriptions are repeated..$^{12,13}$ These medications can cause serious diseases. For example, a cold preparation that can be purchased without prescription can cause organic affective psychosis. ${ }^{14}$ Additionally, it has been observed that commonly used antibiotics lose their effectiveness on bacteria over time. ${ }^{15}$ It is reported that the acetylsalicylic acid in Non-Steroidal Anti-Inflammatory Drugs (NSAID), can cause esophagitis. ${ }^{16}$ It is also a known fact that the unconscious use of various medications often produce more harm than expected therapeutic effect in patients. $7,17,18,19,20$

The duty of pharmacists in the face of these problems is to encourage and promote conscientous drug use by sharing general information about diseases and symptoms with doctors and other healthcare professionals. 5.6

As an indispensable link in the healthcare institution chain, pharmacies should not only sell drugs to patients, but also raise people's awareness about them and, more importantly, prevent the use of inappropriate and unnecessary medications.

The aim of this study is to determine the purposes of the position of pharmacies in primary health care services chain, and to determine the services received from pharmacies, since these change according to the relative distances between pharmacies and health clinics.

\section{METHODOLOGY}

\section{Time and Location of Research}

This research was conducted between August 23rd, 2005 and September 12th, 2005 in Kurklareli (Turkey) a city with a population of 53,221. ${ }^{21}$

The number of pharmacies and pharmacists who completed the survey in Kurklareli province is given in Table 1. Kurklareli lies in the Marmara region of Turkey (Figure 1). 
Table 1: The number of pharmacies and pharmacists who completed the survey in Kırklareli provinces.

\begin{tabular}{|l|l|l|l|}
\hline City of Kırklareli & $\begin{array}{l}\text { Number of } \\
\text { Pharmacy }\end{array}$ & $\begin{array}{l}\text { Number of Pharmacists Who } \\
\text { Complete the Survey }\end{array}$ & $\begin{array}{l}\text { Percentage } \\
\text { (\%) }\end{array}$ \\
\hline Town Center & 36 & 27 & 75.0 \\
\hline Babaeski & 18 & 6 & 33.3 \\
\hline Lüleburgaz & 44 & 14 & 31.8 \\
\hline Pınarhisar & 4 & 2 & 50.0 \\
\hline Vize & 5 & 2 & 40.0 \\
\hline Pehlivanköy & 1 & 1 & 100.0 \\
\hline Demirköy & 2 & 1 & 50.0 \\
\hline Beldeler & 3 & 2 & 66.7 \\
\hline Total & 113 & 55 & \\
\hline
\end{tabular}

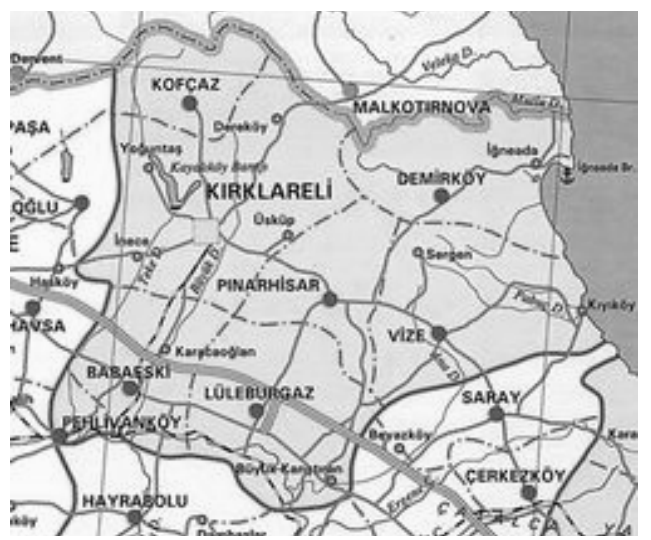

Figure 1: City map of Kırklareli

\section{Data Collection and Evaluation}

Surveys were distributed and collected by the Kurklareli Chamber of Pharmacists, and then given to the researcher. As a preliminary experiment, surveys were distributed to 44 pharmacies in İstanbul/Kadıköy and 23 pharmacists completed it (\%52.27). According to a study of primary health care services by Gül et al., surveys were distributed to a total of 73 pharmacies located on both the Anatolian and European sides of Istanbul. 40 of the 73 pharmacies completed the survey (\%54.8). ${ }^{22}$ According to another study by Gül et al., surveys were distributed to 90 pharmacies in the İstanbul districts of Kadıköy and Fatih. This survey was completed by 73 pharmacists (\%81). ${ }^{23}$ The survey consists of 29 questions, 4 of which are openended. As indicated in the data encoding information given in the appendix, the data was closed, re-coded and entered to the SPSS 8.0 for Windows programme.

A Chi-squared test was used in the statistical evaluation of the research data. 


\section{Ethical Problems}

We told pharmacists that neither their names nor the names of their pharmacies would be used in any kind of verbal or written explanation, and we have honored this commitment.

\section{FINDINGS}

\section{Findings Related To Survey Data}

Table 2: Distribution of Pharmacists by Number of Technicians Employed (Kırklareli, 2005)

\begin{tabular}{|l|l|l|}
\hline Number of Technicians & $\mathbf{n}$ & $\%$ \\
\hline 0 & 1 & 1.9 \\
\hline 1 & 28 & 52.8 \\
\hline 2 & 20 & 37.7 \\
\hline 3 & 4 & 7.6 \\
\hline Total $^{*}$ & 53 & 100.0 \\
\hline
\end{tabular}

*2 pharmacists did not answer this question.

Table 3: Distribution of Technicians by Working Hours (Kırklareli, 2005)

\begin{tabular}{|l|l|l|}
\hline $\begin{array}{l}\text { Working Time of Pharmacy } \\
\text { Technicians (hour/day) }\end{array}$ & $\mathbf{n}$ & \% \\
\hline 7 & 1 & 1.6 \\
\hline 8 & 8 & 12.9 \\
\hline 9 & 6 & 9.7 \\
\hline 10 & 17 & 27.4 \\
\hline 11 & 27 & 43.6 \\
\hline 12 & 3 & 4.8 \\
\hline Total $^{*}$ & 62 & 100.0 \\
\hline
\end{tabular}

*14 pharmacists did not answer this question.

Table 4: Distribution of Technicians by Age (Kırklareli, 2005)

\begin{tabular}{|l|l|l|}
\hline Age of Pharmacy Technicians & $\mathbf{n}$ & \% \\
\hline$<19$ & 8 & 11.8 \\
\hline $20-29$ & 41 & 60.3 \\
\hline $30-39$ & 8 & 11.8 \\
\hline $40-49$ & 5 & 7.3 \\
\hline $50>$ & 6 & 8.8 \\
\hline Total $^{*}$ & 62 & 100.0 \\
\hline
\end{tabular}

${ }^{*} 9$ pharmacists did not answer this question. 
Table 5: Distribution of Technicians by Educational Status (Kırklareli, 2005)

\begin{tabular}{|l|l|l|}
\hline $\begin{array}{l}\text { Educational Status of } \\
\text { Pharmacy Technicians }\end{array}$ & $\mathbf{n}$ & $\mathbf{\%}$ \\
\hline Primary School & 16 & 20 \\
\hline Middle School & 11 & 13.7 \\
\hline High School & 38 & 47.5 \\
\hline University & 15 & 18.8 \\
\hline Total* $^{*}$ & 80 & 100.0 \\
\hline
\end{tabular}

*3 pharmacists did not answer this question.

Table 6: Distribution of Pharmacists by Gender (Kırklareli, 2005)

\begin{tabular}{|l|l|l|}
\hline Gender of Pharmacist & $\mathbf{n}$ & \% \\
\hline Female & 28 & 51.9 \\
\hline Male & 26 & 48.1 \\
\hline Total $^{\boldsymbol{*}}$ & 54 & 100.0 \\
\hline
\end{tabular}

*1 pharmacist did not answer this question.

Table 7: Distribution of Pharmacies Within 150 Meters of A Health Facility. (Kırklareli, 2005)

\begin{tabular}{|l|l|l|}
\hline $\begin{array}{l}\text { Is There A Health Clinic Near } \\
\text { the } \mathbf{1 5 0} \text { Meters of Pharmacy? }\end{array}$ & $\mathbf{n}$ & $\mathbf{\%}$ \\
\hline Yes & 20 & 36.4 \\
\hline No & 35 & 63.6 \\
\hline Total & 55 & 100.0 \\
\hline
\end{tabular}

Table 8: Distribution of Health Facilities Within 150 Meters of a Pharmacy (Kırklareli, 2005)

\begin{tabular}{|l|l|l|}
\hline $\begin{array}{l}\text { Health Facility Type That Near } \\
\text { To } \mathbf{1 5 0} \text { Meters of Pharmacies }\end{array}$ & $\mathbf{n}$ & $\mathbf{\%}$ \\
\hline Health Clinic & 11 & 55.0 \\
\hline Public Hospital & 7 & 35.0 \\
\hline Private Hospital & 2 & 10.0 \\
\hline Private Policlinic & 0 & 0.0 \\
\hline Public Policlinic & 0 & 0.0 \\
\hline Total* & 20 & 100.0 \\
\hline
\end{tabular}

*35 pharmacists did not answer this question. 
Table 9: Distribution of Prescribed Medications Sold in Pharmacies in the Most Recent Week (Kırklareli, 2005)

\begin{tabular}{|l|l|l|}
\hline $\begin{array}{l}\text { Prescripted Medication Groups That Sold in } \\
\text { Pharmacies in the Most Recent Week }\end{array}$ & $\mathbf{n}$ & \% \\
\hline Analgesics & 112 & 19.5 \\
\hline Antibiotics & 74 & 12.9 \\
\hline Antirheumatic Drugs & 65 & 11.3 \\
\hline Antihypertensives etc. & 61 & 10.6 \\
\hline Heart Drugs & 56 & 9.8 \\
\hline Vitamins & 54 & 9.4 \\
\hline Antidepressants & 34 & 5.9 \\
\hline Anti-Flu Medications & 31 & 5.4 \\
\hline Lipid-Lowering Medications & 24 & 4.2 \\
\hline Antihistamines & 17 & 3.0 \\
\hline Hormones & 15 & 2.6 \\
\hline Antiepileptics & 12 & 2.1 \\
\hline Green Prescription Medicines & 10 & 1.7 \\
\hline Aphrodisiacs & 9 & 1.6 \\
\hline Total* & 574 & 100.0 \\
\hline
\end{tabular}

*11 pharmacists did not answer this question.

Table 10: Distribution of Non-Prescribed Medications Sold in Pharmacies in the Most Recent Week (Kırklareli, 2005)

\begin{tabular}{|c|c|c|}
\hline $\begin{array}{l}\text { Prescripted Medication Groups That Sold in } \\
\text { Pharmacies in Last Week }\end{array}$ & $\mathbf{n}$ & $\%$ \\
\hline Analgesics & 42 & 24.1 \\
\hline Antibiotics & 17 & 9.8 \\
\hline Antirheumatic Drugs & 20 & 11.5 \\
\hline Antihypertensives etc. & 9 & 5.2 \\
\hline Heart Drugs & 8 & 4.6 \\
\hline Vitamins & 22 & 12.6 \\
\hline Antidepressants & 7 & 4.1 \\
\hline Anti-Flu Medications & 15 & 8.6 \\
\hline Lipid-Lowering Medications & 2 & 1.1 \\
\hline Antihistamines & 16 & 9.2 \\
\hline Hormones & 7 & 4.1 \\
\hline Antiepileptics & 3 & 1.7 \\
\hline Aphrodisiacs & 6 & 3.4 \\
\hline Total $^{*}$ & 174 & 100.0 \\
\hline
\end{tabular}

${ }^{*} 15$ pharmacists did not answer this question. 
Table 11: Distribution of Herbal Products Sold in Pharmacies in the Most Recent Week (Kırklareli, 2005)

\begin{tabular}{|l|l|l|}
\hline \multirow{2}{*}{$\begin{array}{l}\text { Packaged Herbal Product Groups That } \\
\text { Sold in Pharmacies in Last Week }\end{array}$} & & \\
\cline { 2 - 3 } & $\mathbf{n}$ & $\%$ \\
\hline Weight Loss Preparations & 7 & 63.6 \\
\hline Energizing Products & 3 & 27.3 \\
\hline Dead Nettle Leaf & 1 & 9.1 \\
\hline Sage Tea & 0 & 0.0 \\
\hline Rosehip & 0 & 0.0 \\
\hline Linden & 0 & 0.0 \\
\hline Mint & 0 & 0.0 \\
\hline Senna & 0 & 0.0 \\
\hline Garlic & 0 & 0.0 \\
\hline Total ${ }^{*}$ & 11 & 100.0 \\
\hline
\end{tabular}

*37 pharmacists did not answer this question.

Table 12: Distribution of Patients Willing to Purchase Non-Prescribed Medications From Pharmacies (Gender and Age) (Kırklareli, 2005)

\begin{tabular}{|c|c|c|c|c|}
\hline \multirow[t]{3}{*}{ Age } & \multicolumn{4}{|c|}{ Gender } \\
\hline & \multicolumn{2}{|c|}{ Female } & \multicolumn{2}{|c|}{ Male } \\
\hline & $n$ & $\%$ & $\mathrm{n}$ & $\%$ \\
\hline$<19$ & 33 & 6.9 & 29 & 5.2 \\
\hline $20-29$ & 89 & 18.7 & 108 & 19.5 \\
\hline $30-39$ & 112 & 23.6 & 130 & 23.5 \\
\hline $40-49$ & 129 & 27.2 & 145 & 26.2 \\
\hline $50>$ & 112 & 23.6 & 142 & 25.6 \\
\hline Total* & 475 & 100.0 & 554 & 100.0 \\
\hline
\end{tabular}

*27 pharmacists did not answer this question. 
Table 13: Distribution of Non-Medicinal Products Sold in Pharmacies in the Most Recent Week (Kırklareli, 2005)

\begin{tabular}{|l|l|l|}
\hline $\begin{array}{l}\text { Top-Selling Non-Medication } \\
\text { Products in Last Week }\end{array}$ & $\mathbf{n}$ & \% \\
\hline Pregnancy Tests & 27 & 20.8 \\
\hline Antiseptics e.g. tincture of iode & 24 & 18.5 \\
\hline Plasters & 21 & 16.2 \\
\hline Insecticides & 15 & 11.5 \\
\hline Vitamins & 15 & 11.5 \\
\hline Cosmetics & 10 & 7.7 \\
\hline Baby Products & 9 & 6.9 \\
\hline Family Planning Products & 9 & 6.9 \\
\hline Slipper etc. & 0 & 0.0 \\
\hline Toys & 0 & 0.0 \\
\hline Total ${ }^{*}$ & 130 & 100.0 \\
\hline
\end{tabular}

${ }^{*} 15$ pharmacists did not answer this question.

Table 14: Distribution of Healthcare Professionals Consulted First by Patients About Their Health Complaints (Kırklareli, 2005)

\begin{tabular}{|l|l|l|}
\hline $\begin{array}{l}\text { How Do Patients Report Health } \\
\text { Complaints First? }\end{array}$ & $\mathbf{n}$ & \% \\
\hline To Pharmacist & 26 & 48.1 \\
\hline To Doctor & 28 & 51.9 \\
\hline Total $^{*}$ & 54 & 100.0 \\
\hline
\end{tabular}

*1 pharmacist did not answer this question.

Table 15: Reasons Why Patients First Consult Pharmacists (Kırklareli, 2005)

\begin{tabular}{|l|l|l|}
\hline $\begin{array}{l}\text { Reasons of Consulting } \\
\text { Pharmacist First }\end{array}$ & $\mathbf{n}$ & $\%$ \\
\hline $\begin{array}{l}\text { Because it is free or because } \\
\text { patients do not want to pay for both } \\
\text { a doctor and medicine }\end{array}$ & 15 & 45.45 \\
\hline $\begin{array}{l}\text { Because access to a pharmacist is } \\
\text { easier than access to a doctor }\end{array}$ & 15 & 45.45 \\
\hline $\begin{array}{l}\text { Because patients do not think that } \\
\text { their sickness is serious }\end{array}$ & 3 & 9.10 \\
\hline Total $^{*}$ & 33 & 100.0 \\
\hline
\end{tabular}

${ }^{*} 22$ pharmacists did not answer this question. 
Table 16: Distribution of Warnings by Pharmacists That Patients Should Report Adverse Reactions and/or Side Effects (Kırklareli, 2005)

\begin{tabular}{|l|l|l|}
\hline $\begin{array}{l}\text { Are Warnings that the Drug Needs to be } \\
\text { Reported to the Pharmacy If It Has Adverse } \\
\text { Reactions and / or Side Effects Issued? }\end{array}$ & $\mathbf{n}$ & \% \\
\hline Yes & 42 & 84.0 \\
\hline No & 8 & 16.0 \\
\hline Total $^{*}$ & 50 & 100.0 \\
\hline
\end{tabular}

*5 pharmacists did not answer this question.

Table 17: Distribution of Healthcare Professionals Informed by Patients of Adverse Reactions and/or Side Effects (Kırklareli, 2005)

\begin{tabular}{|l|l|l|}
\hline $\begin{array}{l}\text { Which Healthcare Professionals are Informed } \\
\text { when a Drug Has Adverse Reactions and/or } \\
\text { Side Effects? }\end{array}$ & $\mathbf{n}$ & \% \\
\hline Pharmacist & 30 & 57.7 \\
\hline Doctor & 22 & 42.3 \\
\hline Total $^{*}$ & 52 & 100.0 \\
\hline
\end{tabular}

*3 pharmacists did not answer this question.

Table 18: Distribution of Pharmacist Response to Adverse Reactions and/or Side Effects (Kırklareli, 2005)

\begin{tabular}{|c|c|c|}
\hline \multirow{2}{*}{$\begin{array}{l}\text { What is being done by pharmacists for those } \\
\text { who complain of adverse reactions and/or side } \\
\text { effects of drugs? }\end{array}$} & \multirow[b]{2}{*}{$\mathrm{n}$} & \multirow[b]{2}{*}{$\%$} \\
\hline & & \\
\hline I guide the patient to a health facility & 49 & 98.0 \\
\hline I intervene with the patient & 1 & 2.0 \\
\hline I guide the patient to a private doctor & 0 & 0.0 \\
\hline I call the pharmaceutical company & 0 & 0.0 \\
\hline Total* & 50 & 100.0 \\
\hline
\end{tabular}

*5 pharmacists did not answer this question.

Table 19: Distribution of Applications to Pharmacists About Drug Poisoning (Kırklareli, 2005)

\begin{tabular}{|l|l|l|}
\hline \multirow{2}{*}{$\begin{array}{l}\text { Are there any Applications About Drug } \\
\text { Poisoning? }\end{array}$} & & \\
\cline { 2 - 3 } & $\mathbf{n}$ & $\%$ \\
\hline Yes & 3 & 5.7 \\
\hline No & 50 & 94.3 \\
\hline Total $^{*}$ & 53 & 100.0 \\
\hline
\end{tabular}

*2 pharmacists did not answer this question. 
Table 20: Distribution of Pharmacist Response to Drug Poisoning (Kırklareli, 2005)

\begin{tabular}{|l|l|l|}
\hline $\begin{array}{l}\text { What is being done by pharmacists for } \\
\text { those who encounter drug poisoning? }\end{array}$ & $\mathbf{n}$ & \% \\
\hline I guide the patient to a health facility & 3 & 100.0 \\
\hline I intervene with the patient & 0 & 0.0 \\
\hline I guide the patient to a private doctor & 0 & 0.0 \\
\hline Other & 0 & 0.0 \\
\hline Total $^{*}$ & 3 & 100.0 \\
\hline
\end{tabular}

*52 pharmacists did not answer this question.

Table 21: Distribution of Non-Drug-Requests by Patients in the Most Recent Week (Kırklareli, 2005)

\begin{tabular}{|l|l|l|}
\hline Services & $\mathbf{n}$ & \% \\
\hline Drug counseling & 23 & 82.1 \\
\hline Preparation of Solution/Drug & 4 & 14.3 \\
\hline Bandages & 1 & 3.6 \\
\hline Total $^{*}$ & 28 & 100.0 \\
\hline
\end{tabular}

*26 pharmacists did not answer this question.

Table 22: Distribution of Consultation with Pharmacy for HIV Tests in the Most Recent Week (Kırklareli, 2005)

\begin{tabular}{|l|l|l|}
\hline $\begin{array}{l}\text { Has any kind of help been requested } \\
\text { regarding HIV tests in the past week? }\end{array}$ & $\mathbf{n}$ & $\mathbf{\%}$ \\
\hline Yes & 0 & 0.0 \\
\hline No & 51 & 100.0 \\
\hline Total $^{*}$ & 51 & 100.0 \\
\hline
\end{tabular}

*4 pharmacists did not answer this question.

Table 23: Distribution of Terminating Drug Supplies in the Most Recent Week (Kırklareli, 2005)

\begin{tabular}{|l|l|l|}
\hline $\begin{array}{l}\text { Drug Supplies for Terminating } \\
\text { Pregnancy }\end{array}$ & $\mathbf{n}$ & \% \\
\hline Yes & 7 & 13.7 \\
\hline No & 44 & 86.3 \\
\hline Total $^{*}$ & 51 & 100.0 \\
\hline
\end{tabular}

*4 pharmacists did not answer this question. 
Table 24: Distribution of Pharmacists Responses to Patients Wishing to Terminate Pregnancy (Kırklareli, 2005)

\begin{tabular}{|l|l|l|}
\hline $\begin{array}{l}\text { How are Patients guided by Pharmacists About } \\
\text { Terminating Pregnancy? }\end{array}$ & $\mathbf{n}$ & \% \\
\hline I guide the patient to a doctor & 3 & 42.9 \\
\hline $\begin{array}{l}\text { In the first } 12 \text { hours I suggest estrogen at } 100 \mathrm{mg} \text { a day, } \\
\text { after } 72 \text { hours, I suggest another } 100 \mathrm{mg} \text { of estrogen }\end{array}$ & 2 & 28.5 \\
\hline I guide the patient to a health facility & 1 & 14.3 \\
\hline I do not give any service & 1 & 14.3 \\
\hline Total $^{*}$ & 7 & 100.0 \\
\hline
\end{tabular}

*49 pharmacists did not answer this question.

Table 25: Distribution of Family Planning Methods Purchased in the Most Recent Week (Kırklareli, 2005)

\begin{tabular}{|l|l|l|}
\hline Family Planning Methods & $\mathbf{n}$ & $\mathbf{\%}$ \\
\hline Oral contraceptives & 17 & 43.5 \\
\hline Male condoms & 15 & 38.5 \\
\hline Suppository, foam, gel & 5 & 12.8 \\
\hline Female condoms & 1 & 2.6 \\
\hline Intrauterine devices & 1 & 2.6 \\
\hline Diaphragma & 0 & 0.0 \\
\hline Total $^{*}$ & 39 & 100.0 \\
\hline
\end{tabular}

*12 pharmacists did not answer this question.

Table 26: Distribution of Approvals by Pharmacists About the Selling of Over-The-Counter Drugs Outside of Pharmacies (Kırklareli, 2005)

\begin{tabular}{|l|l|l|}
\hline $\begin{array}{l}\text { Do pharmacists approve the selling of over-the- } \\
\text { counter drugs outside of pharmacies? }\end{array}$ & $\mathbf{n}$ & $\mathbf{\%}$ \\
\hline Yes & 2 & 5.9 \\
\hline No & 32 & 94.1 \\
\hline Total $^{\star}$ & 34 & 100.0 \\
\hline
\end{tabular}

*21 pharmacists did not answer this question.

Table 27: First Application Place to a Pharmacy Within 150 Meters of a Health Facility (Kırklareli, 2005)

\begin{tabular}{|l|l|l|l|l|l|l|l|}
\hline \multirow{2}{*}{$\begin{array}{l}\text { Is there a health facility within } \\
\text { 150 meters of the pharmacy? }\end{array}$} & \multicolumn{2}{|l|}{ First Professional Sought in Complaints } & \multicolumn{2}{|c|}{ Total } \\
\cline { 2 - 7 } & Firstly Doctor & \multicolumn{2}{|l|}{ Firstly Pharmacist } & \multicolumn{2}{|l|}{} \\
\cline { 2 - 7 } & $\mathrm{n}$ & $\%$ & $\mathrm{n}$ & $\%$ & $\mathrm{n}$ & $\%$ \\
\hline Yes & 7 & 36.8 & 12 & 63.2 & 19 & 100 \\
\hline No & 19 & 54.3 & 16 & 45.7 & 35 & 100 \\
\hline Total & 26 & 48.1 & 28 & 51.9 & 54 & 100 \\
\hline
\end{tabular}

$\mathrm{X}^{2}=1.501 \mathrm{p}=0.221$ 
Table 28: Distribution of Consultatitons for Terminating Pregnancy According to the Gender of the Pharmacist (Kırklareli, 2005)

\begin{tabular}{|c|c|c|c|c|}
\hline \multirow{3}{*}{ Gender of Pharmacist } & \multicolumn{4}{|c|}{ Requesting Help for Terminating Pregnancy } \\
\hline & \multicolumn{2}{|c|}{ Total } & \multicolumn{2}{|c|}{ Yes } \\
\hline & $\mathbf{n}$ & $\%$ & n & $\%$ \\
\hline Male & 26 & 52 & 2 & 28.6 \\
\hline Female & 24 & 48 & 5 & 71.4 \\
\hline Total & 50 & 100 & 7 & 100 \\
\hline
\end{tabular}

fisher exact test $=0.239$

\section{DISCUSSION AND CONCLUSION}

This research was conducted between August 23rd, 2005 and September 12th, 2005 in Kirklareli. 55 of the 113 pharmacists who registered with the Chamber of Pharmacists (Table 1). According to a study of primary health care services by Gül et al., surveys were distributed to 73 pharmacies located on both Anatolian and European sides of İstanbul. And 40 pharmacies completed the survey (\%54.8). ${ }^{22}$ According to another study of primary health care services by Gül and his associates, surveys were distributed to 90 pharmacies in the Kadıköy and Fatih districts of İstanbul. That survey was completed by 73 pharmacists (\%81). ${ }^{23}$ The survey consists of 29 questions, 4 of which are open-ended. As indicated in the data encoding information in the appendix, the data was closed, re-coded and entered to the SPSS 8.o for Windows programme.

In this study, we learn that $52.8 \%$ of pharmacists have only one technician as indicated in Table 2. Additionally, the ratio of pharmacists working with 2 technicians was 37.7\%. Gürses and Aran et al. also shows that pharmacists work with one or two technicians. ${ }^{24}$ The pharmacists in our research region state that one or two technicians are sufficient for general pharmacy works, considering the population. In Table 3, percentage of pharmacists whose technicians work 7, 8, 10, 11 and 12 hours a day were determined as 1.6\%, 12.9\%, 27.4\%, 43.6\%, and 4.8\%, respectively.

Table 4 indicates that the age range of technicians is mostly between 20-29. Gürses and Aran et al. stated that the age range of technicians is primarily $25-34 \cdot{ }^{24}$ Since the technicians are relatively young, $43.5 \%$ of them work 11 hours a day. In Table 5, percentage of technicians at with a high school diploma or higher is $66.3 \%$. All of technicians who are university graduates are close relatives of pharmacists. According to a study conducted by Boztok et al. in İzmir, $46.7 \%$ of technicians held a high school diploma or higher. ${ }^{25}$ The gender of the pharmacists who participated in this study are shown in Table 6; the percentage of female pharmacists is $51.9 \%$ while ratio of male pharmacists was $48.1 \%$. Thus there is an equal gender distribution with regard to gender. Table 7 shows the 
distribution of pharmacies that are within 150 meters of a health facility. The percentage of pharmacies with no health facility within 150 meters is $63.6 \%$.

Table 8 indicates that $55 \%$ of health facilities within 150 meters of pharmacies are health clinics. According to Boztok, $48.7 \%$ of health facilities in closest proximity to a pharmacy are health clinics. ${ }^{25}$ Thus it can be seen that health clinics are the most common health facilities and patients can easily reach a pharmacy after leaving a health clinic. Table 9 illustrates that the highest rate of patients visited pharmacies to purchase prescribed-analgesics (19.55\%) in the most recent week of the study. The products with the lowest rate of purchase were aphrodisiacs (1.6\%).

Table 10 shows that the top-selling products without a prescription were analgesics, vitamins and antirheumatic drugs. Generally, antibiotics are used for upper respiratory tract infections like tonsillitis, pharyngitis and laryngitis. There is a decrease in the sale of heart medicines and antihypertensives because elderly patients generally go to areas with warmer climates in the Summer season. According to Boztok, 35.6\% of all medicines sold in pharmacies are analgesics and antirheumatic drugs. ${ }^{25}$ According to another study by Hannay, the most commonly used non-prescription drugs are antipyretics, analgesics, antitussive drugs and laxatives, respectively. ${ }^{26}$ According to Vicencio et al., the drugs that are sold most are analgesics, NSAID's and vitamins. ${ }^{27}$ In Table 9 sales of aphrodisiacs occur at a rate of $1.6 \%$, whereas in Table 10 , sales of aphrodisiacs occur at a rate of $3.4 \%$, an indication that more aphrodisiacs are being sold.

The excessive sale of weight-loss and energy products is attributed to excessive advertising for these products (Table 11). The majority of male patients who want to buy medicines without prescriptions are over the age 40. There is not a significant difference between males and females by gender in the frequency of medicine purchase (Table 12). It is reported that pregnancy test products are the most popular non-medicinal products with a rate of \%20.6 in the most recent week of the study. The least-sold products are toys, slippers etc. (Table 13).

Patients apply first to doctors and then to pharmacists with rates of \%51.9 and $\% 48.1$ respectively with their complaints (Table 14). In a study conducted in Ankara by Onaran, patients applied first to pharmacists for their complaints at a rate of $\% 43.8 .^{28}$ We think that pharmacies play a key role in this situation because they are well-educated and easily accessible. When evaluating the reasons for applications to pharmacists by patients, the fact that pharmacies are free and easily reachable, and those patients' complaints are not significant are the reasons not to visit a doctor (Table 15).

According to Table 16, 84\% of pharmacists warn patients that they should report 
adverse reactions and/or side effects of medications when they occur, and $57.7 \%$ of patients report adverse reactions and/or side effects to pharmacists first (Table 17). According to a study conducted by Uğraşbul and Sütaş in İzmit, $62.1 \%$ of patients report the adverse reactions and/or side effects to pharmacists first. 92.2\% of pharmacists guided such patients to a health facility. Table 18 shows that $98 \%$ of pharmacists guided patients who report adverse reactions and/or side effects to a health facility. Pharmacists also report the adverse reactions and/or side effects of these medications to TÜFAM (The National Pharmacovigilance Centre in Turkey).

According to our study, $94.3 \%$ of pharmacists report that there are no applications for drug poisoning (Table 19). All of the pharmacists guided patients with drug poisoning to a health facility (Table 20). We think that patients apply to pharmacies first because they are more common than health facilities.

According to Table 21, the percentage of patients who come to a pharmacy for drug counseling $82.1 \%$. According to another study, this percentage is $28.8 \%{ }^{24}$ It can be seen that patients mostly get help from pharmacies for purchasing and counseling about medicine.

Our study shows that the number of patients who come to the pharmacy for counseling about HIV tests is very low. It can be thought that reason for this situation is patients' concerns over privacy or embarrassment (Table 22). The reason for our HIV test research is that Kurklareli is a borderline province and HIV tests are sold in pharmacies.

Oral contraceptives are given to $13.7 \%$ of patients who want to terminate pregnancy by $45.5 \%$ of pharmacists, acccording to Tables 23 and 25 . When evaluating the question in Table 24 (to which only 7 pharmacists responded) it is seen that $42.9 \%$ of pharmacists guided patients to a doctor willing to help in terminating pregnancy. In another study conducted by Uğraşbul and Sütaş in İzmit, $32.6 \%$ of pharmacists sold patients the necessary medicine, whereas $27.2 \%$ of pharmacists guided patients to a health facility. ${ }^{29}$ Our study shows that the most preferred methods for family planning are oral contraceptives and male condoms at rates of $43.5 \%$ and $38.5 \%$, respectively. Oral contraceptives can also be used for treating acne vulgaris and as a hormone replacement treatment (Table 25). According to a study conducted by Boztok in İzmir, male condoms and oral contraceptives are the most preferred method for family planning at rates of $40.7 \%$ and $38.9 \%$, respectively. ${ }^{25}$ It can be seen that the most preferred methods are the safest methods.

94.1\% of pharmacists oppose selling over-the-counter medicines outside of pharmacies (Table 26). In a study conducted by Boztok, 97.6\% of pharmacists 
oppose the selling of over-the-counter medicines outside of pharmacies, and state that these kinds of medicines need to be sold in pharmacies. ${ }^{25}$ McFadyen et al. reported that the incorrect use of over-the-counter medicines like insomnia pills, codeine, drugs that contain caffeine or pseudoephedrine, antitussive mixtures, laxatives and especially some analgesics is common. ${ }^{30}$ Deshpande and Tiwari show that $31 \%$ of patients use over-the-counter medicines. $26.9 \%$ of such patients are between the ages of $31-40$, and $30.8 \%$ are in the $41-50$ age range. The use of these medications is more common in men than in women. ${ }^{50}$

Table 27 shows that pharmacists were applied to first by patients when drug side effects occurred $51.9 \%$ of the time. $63.2 \%$ of these pharmacists state that a health facility exists within 150 meters of their pharmacy. The location of the first application differs depending on whether there is a health facility within 50 meters of the pharmacy.

There is no significant statistical difference between genders of pharmacists about requesting help for terminating pregnancy (Table 28). A small number of patients prefer female pharmacists to male pharmacists when seeking help in terminating pregnancy.

When evaluating the open-ended question that asks how cold-chain vaccine application is performed, it can be seen that pharmacists pay attention to storage conditions and sale style. It is understood that pharmacists bring cold environment vaccines from a pharmaceutical warehouse, store them in a fridge, and sell them patients with ice or an ice gauge. Most of applications by patients to pharmacists are about conditions like diarrhea, pain, cold and the use of medicines.

It is thought that the most effective way to counter non-prescription drug use is state policy and community education. When investigating how patients behave when they get sick, it is seen that first, they try to cure themselves, and if this doesn't work, they apply to the nearest health facility, which is generally a pharmacy. Finally, if patients think that their condition is serious, they apply to a doctor. It is thought that the best way to solve this problem is to make people adopt the correct treatment methods by raising public awareness.

\section{Suggestions That Can Be Offered As A Result of This Study}

- All doctors and pharmacists should be encouraged to attend at least one symposium about medication and its developments, regardless of whether they are private or public sector workers.

- Authority sharing of all health care professionals should be determined by comprehensive research, and all health care professionals should be encouraged to comply with these results. 
- Use of non-prescription medication should definitely be prevented. A list of medications that can be sold without prescription should be compiled and results should be announced to doctors and pharmacists by the health authorities.

- The public should be provided with information about the incorrect use of medication through publishing campaign programmes in newspapers, magazines, television and radio.

- Scientific research should be made about the reasons for the use of medication without a prescription.

- The public should be encouraged to use prescription medication by making health insurance more common.

\section{REFERENCES}

1. Hayran O., Sur H.: Health Services Handbook, Marmara University, Istanbul, 1998, p. 27 (in Turkish).

2. Fişek H.N.: Introduction to Public Health. Volume 2, Hacettepe University, Ankara, 1985, p. 4-6 (in Turkish).

3. Helman C.G.: Culture Health and Illness, Buttenvorth-Heineman, London, 1990, p. 55-59.

4. Hayran O., Sur H.: Hospital Management, Marmara University, Istanbul, 1997, p. 15-17.

5. Pharmacists Working for the Benefit of Society. Hacettepe Bulletin of Community Medicine (Special Supplement), 1986, 3, (4) (in Turkish).

6. Hammarstrom B., Westerholm, B.: Pharmacists To The Fore. World Health Forum, 1988, 9(4): 514-518.

7. Thomson G., Sterlcy G.: Self Prescribing By Way of Pharmacies in Three Asian Developing Countries. Lancet, 1986, 2 (8507): 620 - 622.

8. Semin S.: Changes in the Field of Day-To-Day Health Care, 1980. T.T.B. Izmir Medical Chamber Bulletin. Special Issue 1993, 12 (in Turkish).

9. Akalın İ.: Unnecessary Drug Use and Waste Meeting. Conference Hall of T.E.B., 1986 (in Turkish).

10. Kıran B: İzmir- Investigation of Knowledge, Attitudes and Behaviors of Women About Drug Use in Narlıdere Health Care Center Area. D.E.U. Institute of Health Sciences, Master Thesis, Izmir, 1991 (in Turkish).

11. Queneau P., Decousus H., Jourlin M., Laurent H., Perpoint B.: Rheumatic Diseases, Self Medication. Rev. Rhum. Mal. Osteoartic., 1935, 52 (2): 79-84.

12. Martin S.: Pharmaceutical Care Made Easy. Am Pharm., 1994, 34 (3): 61-64.

13. Rucker T.D.: Problem Solving, The Professional Responsibility of Pharmacists. Drug Intern. Clin. Pharm., 1986, 20 (7). 556 - 560.

14. Brown T.M., Golden R.N., Evans D.L.: Organic Affective Psychcosis Associated with the Routine Use of Non- Prescription Cold Preparations. J. Psychiatry., 1990, 156: 572 - 575.

15. Gürler N., Töreci K.: Development of Resistance to Antibiotics in Staphylococci and Their 
Problems. Infection Journal, 1990, 4 (4): 699-716.

16. Kim S.L., Hunter J.G., Wo J.M, Davis L.P., Waring J.P.: NSAIDs, Aspirin And Esophageal Strictures: Are Over Tunter Medications Harmful The Esophagus. J. Clin. Gastroenterol., 1999, 29 (1): 32-34.

17. Feldman E.G.: Solving the Orphan Drug Problem. J. Pharm. Sci., 1982, 71 (11): 1191,.

18. Strom B.L., Taragin M.I., Garson J.L.: Gastrointestinail Bleeding From NSATDs. Agents Actions., (Suppl.) 1990, 29: 27-38.

19. Meyers F.H., Jawetz F., Göldfien A.: Review of Medical Pharmacology. University of California, 1980, p. 40 - 41, California.

20. Kayaalp O.: Medical Pharmacology, Hacettepe University, Ankara, Volume 1, 1989, p. 1 - 11 (in Turkish).

21. Kırklareli Population Directorate Records, 2000.

22. Gül H., Omurtag G.Z., Tozan A., Özden Y.: The Role of Turkish Pharmacists in Health Care: A Research in Province of Istanbul, 10th International Congress of Toxicology (ICTX), Tampere, Finland, Toxicology and Applied Pharmacology , (P-311, 205-206, Poster Presentation), (11-15 July, 2004).

23. Gül H., Omurtag G., Önal A.E., Tozan A., Özel S., Özden Y.I.: Prescription-Non-Prescription Drug Consumption And Factors Affecting in Istanbul, 9. National Public Health Days-GATA (Environmental Health), Poster Presentation, P-214, 145, Kuzılcahamam-Ankara, 28 September-1 October (2005) (in Turkish).

24. Gürses B., Aran S.: The Role of Pharmacists in Primary Care. M.U. Faculty of Medicine, Department of Public Health, Internship Study, Bekirdere, 1991 (in Turkish).

25. Boztok N.: Primary Health Care and Pharmacies. D.E.U. Institute for Health Sciences, Master Thesis, İzmir, 1992 (Supervisor: Assoc. Prof. Dr. Z. Amato) (in Turkish).

26. Hannay D.R.: The Symptom Iceberg: A Study of Community Health. London: Routledge and Kegan Paul, 1979.

27. Vicencio A.D., Alfaro, V.A., Martinez, T.J.L.: Characteristics of Drug Acquisition in Morelia (Michoacan), Mexico Boletin De La Oficina Sanitaria Panamericana, 1995, 3: 236242.

28. Onaran Y.S.: A Research on Knowledge and Expectations of Pharmacy Services in Society. H.U. Institute of Health Sciences, Master Thesis, Ankara, 1994 (Supervisor: Prof. Dr. İ. Üstel) (in Turkish).

29. Uğraşbul F., Sütaş Y.: Primary Health Care and Pharmacies. M.U. Department of Public Health, Internship Study, Izmit, 1991 (in Turkish).

30. MacFadyen L, Eadie D, McGowan T.: Community Pharmacists' Experience of Over-TheCounter Medicine Misuse in Scotland. J. R. Soc. Health., 2001, 121: 185-192.

31. Deshpande SG, Tiwari R. Self Medication-A Growing Concern. Indian J. Med. Sci., 1997, 51: 93-96.

(Received o9 March 2017; accepted 31 March 2017) 